\title{
Ventilation and gas exchange in two turtles: Podocnemis unifilis and Phrynops geoffroanus (Testudines: Pleurodira)
}

\author{
Tábata E.F. Cordeiro a ${ }^{a}$ Augusto S. Abe ${ }^{\mathrm{b}, \mathrm{c}}$, Wilfried Klein ${ }^{\mathrm{c}, \mathrm{d}, *}$ \\ a Master Program in Animal Diversity, Federal University of Bahia, Brazil \\ b State University of São Paulo, Rio Claro, Brazil \\ ${ }^{c}$ National Institute of Science and Technology of Comparative Physiology, Brazil \\ d School of Philosophy, Sciences and Literature Ribeirão Preto, University of São Paulo, Brazil
}

\section{A R T I C L E I N F O}

Article history:

Accepted 15 December 2014

Available online 20 December 2014

\section{Keywords:}

Normoxia

Hypoxia

Hypercarbia

Oxygen consumption

Cost of breathing

Reptilia

\begin{abstract}
A B S T R A C T
Turtles (Testudines) have two major taxa, Pleurodira and Cryptodira. To date, only limited data are available regarding the respiratory physiology of pleurodirans. To begin to address this, we studied ventilation and gas exchange in Podocnemis unifilis and Phrynops geoffroanus. Breathing pattern in both species could be described as episodic with breathing episodes separated by large non-ventilatory periods. We measured duration of inspiration and expiration, breathing frequency, duration of the non-ventilatory period (time between episodes), tidal volume, and oxygen consumption when breathing normoxia, hypoxia and hypercarbia at $25^{\circ} \mathrm{C}$. In both species hypercarbia caused a greater increase in ventilation compared to hypoxia, increasing both breathing frequency and tidal volume. Minute ventilation and oxygen consumption in P. geoffroanus were the lowest described so far in testudines, indicating either extra-pulmonary gas exchange or a significantly lower metabolism. Oxidative costs of breathing, estimated using the regression method, was the highest described so far for any reptile. Further studies are necessary to better understand respiratory physiology in Phrynops and Podocnemis species.
\end{abstract}

(C) 2014 Elsevier B.V. All rights reserved.

\section{Introduction}

Aspiration breathing occurs in amniotes through passive expansion of the lungs by contraction of skeletal muscles (Brainerd, 1999). These muscles, which may work alone or together to cause inspiratory air flow, are the intercostal muscles, abdominal muscles or some derived form like the mammalian or crocodilian diaphragmaticus muscles (Brainerd and Owerkowicz, 2006; Klein and Owerkowicz, 2006). Testudines possess a rigid shell with immovable ribs and face the problem of ventilating their lungs within this encasement. Due to the constraints of a rigid shell on ventilation, functional morphology of the respiratory system and mechanics of breathing in turtles has been of interest to scientists for centuries (Bojanus, 1821; Druzisky and Brainerd, 2001; Gans and Hughes, 1967; Gaunt and Gans, 1969; Hansemann, 1915; Jackson, 1971; Lambertz et al., 2010; Landberg et al., 2003; Landberg et al.,

\footnotetext{
约 This paper is part of a special issue entitled "Comparative Physiology of respiratory networks", guest-edited Dr. Richard J.A. Wilson.

* Corresponding author at: Departamento de Biologia, Faculdade de Filosofia, Ciências e Letras de Ribeirão Preto, Universidade de São Paulo, Av. Bandeirantes 3900, Bairro Monte Alegre, CEP: 14040-901 Ribeirão Preto, SP, Brazil. Tel.: +55 1633150452; fax: +55 1633154886 .

E-mail addresses: wklein@usp.br, klein@ffclrp.usp.br (W. Klein).
}

2009; McCutcheon, 1943; Milsom and Johansen, 1975; Mitchell and Morehouse, 1863; Shah, 1962; Shaw and Baldwin, 1935; Townson, 1799; Vitalis and Milsom, 1986a,b). Testudines' solution for their morphological constraint on breathing is to perform ventilatory movements using groups of abdominal muscles associated with their legs (Gans and Hughes, 1967; Gaunt and Gans, 1969). Contractions of these muscles move the viscera and thereby compress or expand the lungs resulting in inspiration or expiration (Gans and Hughes, 1967; Gaunt and Gans, 1969). Ventilatory movements powered by these muscles are carried out at optimal combinations of breathing frequency and tidal volume, thereby keeping the mechanical work of breathing at a minimum (Vitalis and Milsom, 1986a,b).

Estimates of the oxidative cost of ventilation in turtles, however, have yielded significantly different values. Kinney and White (1977) estimated metabolic cost of breathing in Pseudemys floridana to be around $10 \%$ of resting metabolic rate (RMR) at $37^{\circ} \mathrm{C}$, increasing up to $30 \%$ of RMR at $10^{\circ} \mathrm{C}$ body temperature. Using a different methodological approach, Jackson et al. (1991) obtained a metabolic cost of breathing of less than $1 \%$ of RMR at $25^{\circ} \mathrm{C}$ in Chrysemys picta bellii. The controversy regarding metabolic cost of breathing is not restricted to turtles, since similar variation has been found in other reptiles. Wang and Warburton (1995), studying Alligator mississippiensis, found metabolic cost of breathing to be 
15\% of RMR during hypoxic and 1-5\% of RMR during hypercarbic exposures. In Tupinambis merianae, Skovgaard and Wang (2004) estimated metabolic cost of breathing to be $17 \%$ of RMR during hypoxia and less than $1 \%$ of RMR during hypercarbia.

The taxon Testudines is composed of Pleurodira (side-neck turtles) and Cryptodira (freshwater turtles, sea turtles, snapping turtles, soft shell turtles, tortoises). Very few data are available regarding lung ventilation in side-neck turtles (Burggren et al., 1977; Glass et al., 1978a) and our ideas about turtle ventilation and gas exchange are mainly based on studies using cryptodires. Since Pleurodira and Cryptodira form separate phylogenetic lineages for about 150 million years (Sterli et al., 2013) it is of interest to study ventilation and gas exchange in pleurodiran species and compare these data with available data from cryptodiran species. In the present study we measured ventilation in the yellow-spotted river turtle (Podocnemis unifilis) and in Geoffroy's side-necked turtle (Phrynops geoffroanus) during normoxia as well as during hypoxic and hypercarbic exposures with the aim to calculate oxidative cost of breathing in these pleurodiran species.

\section{Materials and methods}

\subsection{Animals}

Adult individuals of both sexes of $P$. unifilis $\left(M_{\mathrm{B}}=0.875 \pm\right.$ $0.085 \mathrm{~kg} ; N=5)$ and $P$. geoffroanus $\left(M_{\mathrm{B}}=1.872 \pm 0.288 \mathrm{~kg} ; N=6\right)$ living under natural conditions were obtained from the Jacarezário, Universidade Estadual Paulista "Júlio de Mesquita Filho", Rio Claro, SP, Brazil and maintained for 3-5 month before experimentation to acclimate to laboratory conditions at the University of São Paulo in Ribeirão Preto, SP, Brazil. Experiments were performed between September and December and animals were used under licence number 35221-1 (SISBIO, Brazil) and animal care protocol number 12.1.1541.53.0 (CEUA USP/Campus de Ribeirão Preto).

\subsection{Setup}

Ventilation and gas exchange was measured following Glass et al. (1978b), Wang and Warburton (1995) and Silva et al. (2011). Feeding was suspended seven days before experimentation. Individuals were placed into a chamber filled with water which was sealed with a lid so that animals had to breathe into a funnel. This chamber was placed into an aquarium to maintain water temperature at $25 \pm 1{ }^{\circ} \mathrm{C}$. The size of the animal chamber was adapted to the size of each species, restricting the animal's movements. To breathe, an individual only needed to extend its neck and protrude its nostrils into the funnel. The funnel aperture was connected to a pneumotach (Fleisch tube) which was in turn connected to a spirometer (FE141 ADInstruments). Air inside the funnel was sampled, dried, and pushed to a gas analyser (ML206 ADInstruments). Data were recorded and analysed using Powerlab and LabChart 7.0 (AdInstruments). The spirometer and funnel were calibrated by injecting known volumes of gas using syringes; air was used for the spirometer calibration and different volumes of $\mathrm{O}_{2}$ and $\mathrm{CO}_{2}$ were used to calibrate the gas exchange measurements. Regression lines resulting from these calibrations showed good fit $\left(R^{2}>0.9\right)$ and were used to calculate tidal volume $\left(V_{\mathrm{T}}\right)$, oxygen consumption $\left(\dot{V}_{\mathrm{O}_{2}}\right)$ and carbon dioxide production $\left(\dot{V}_{\mathrm{CO}_{2}}\right)$.

Gas mixtures were provided using a Pegas gas mixer (COLUMBUS) at a constant flow rate of $21 / \mathrm{min}$, directed into the funnel.

\subsection{Experimental protocol}

Animals were placed into the experimental setup at least $12 \mathrm{~h}$ before any measurements. Ventilation and gas exchange were measured initially for $2 \mathrm{~h}$ during normoxic conditions, followed by progressively decreasing hypoxic $\left(9,7,5,3 \% \mathrm{O}_{2}\right)$ or progressively increasing hypercarbic $\left(1.5,3.0,4.5,6.0 \% \mathrm{CO}_{2}\right)$ exposures, with the animals being exposed to each gas mixture for $2 \mathrm{~h}$.

\subsection{Data analysis}

At each gas mixture, the last 30 min of exposure were used to extract the following data: breathing frequency $\left(f_{\mathrm{R}}\right)$, breathing frequency during breathing episodes $\left(f_{\text {Repi }}\right)$, tidal volume $\left(V_{\mathrm{T}}\right)$, duration of expiration ( $\left.T_{\mathrm{EXP}}\right)$, duration of inspiration $\left(T_{\mathrm{INSP}}\right)$, total duration of one ventilatory cycle $\left(T_{\mathrm{TOT}}=T_{\mathrm{EXP}}+T_{\mathrm{INSP}}\right)$, duration of non-ventilatory period $\left(T_{\mathrm{NVP}}\right)$, and oxygen consumption $\left(V_{\mathrm{O}_{2}}\right)$. From these data minute ventilation $\left(\dot{V}_{\mathrm{E}}\right)$, oxygen consumption $\left(\dot{V}_{\mathrm{O}_{2}}\right)$, and air convection requirement $\left(\dot{V}_{\mathrm{E}} / \dot{V}_{\mathrm{O}_{2}}\right)$ were calculated.

Data were analysed using GraphPad Prism 6.0 applying Repeated Measures ANOVA followed by a Tukey's multiple comparison test. A value of $P<0.05$ was considered significant.

\section{Results}

Breathing pattern in both species can be described as episodic with large non-ventilatory periods between breathing episodes (Fig. 1). A ventilatory cycle starts with an expiration followed by an inspiration, which are of equal duration in both species, and under normoxia $P$. unifilis spends half the time in inspiration and expiration than $P$. geoffroanus (Fig. 2). Hypoxic exposure elicits small changes in the above pattern, not significantly altering $T_{\text {INSP }}, T_{\text {EXP }}$ and $T_{\text {TOT }}$ in either species (Fig. 2 ), but significantly reducing $f_{\text {Repi }}$ at all hypoxic levels in $P$. unifilis and at 7 and $5 \% \mathrm{O}_{2}$ in $P$. geoffroanus (Fig. 1a). Hypercarbia, on the other hand, significantly increases $T_{\text {INS }}$ and $T_{\mathrm{TOT}}$ in $P$. geoffroanus (Fig. $2 \mathrm{~b}$ and $\mathrm{f}$ ) and significantly increases $f_{\text {Repi }}$ in P. unifilis (Fig. 1b). Overall $f_{\mathrm{R}}$ changes significantly during 3\% hypoxia only in $P$. geoffroanus but during hypercarbia both species increase $f_{\mathrm{R}}$ significantly (Fig. $3 \mathrm{a}$ and $\mathrm{b}$ ), $P$. geoffroanus only at $6 \%$ $\mathrm{CO}_{2}$, but $P$. unifilis at $3.0,4.5$, and $6.0 \% \mathrm{CO}_{2}$. The increase in $f_{\mathrm{R}}$ during hypercarbia significantly reduces $T_{\mathrm{NVP}}$ in both species (Fig. 1d). During hypoxia, $T_{\mathrm{NVP}}$ showed a significant reduction in both species at $3 \% \mathrm{O}_{2}$ (Fig. 1c).

Compared to normoxia, $V_{\mathrm{T}}$ and $\dot{V}_{\mathrm{E}}$ increased significantly at the lowest $\mathrm{O}_{2}$ and greatest $\mathrm{CO}_{2}$ concentration in both species, respectively. This increase, however, was more pronounced in $P$. unifilis during hypercarbia (Fig. 3). Oxygen consumption did not change in $P$. unifilis during hypoxia but increased significantly during hypercarbia, whereas in $P$. geoffroanus $\dot{V}_{\mathrm{O}_{2}}$ increased significantly at 3 and $5 \%$ oxygen but was unaffected by hypercarbia (Fig. $4 \mathrm{a}$ and b). Air convection requirement did increase significantly at $3 \% \mathrm{O}_{2}$ when compared to normoxia in $P$. geoffroanus, but was unaffected in P. unifilis (Fig. 4c). Under hypercarbia, $\dot{V}_{\mathrm{E}} / \dot{V}_{\mathrm{O}_{2}}$ increased in both species, being significantly different from normoxic values at $6 \%$ $\mathrm{CO}_{2}$ in P. geoffroanus and $4.5 \% \mathrm{CO}_{2}$ in P. unifilis, respectively (Fig. $4 \mathrm{~d}$ ).

\section{Discussion}

\subsection{Normoxic conditions}

Breathing pattern in both species followed the general chelonian pattern of episodic breathing, where long non-ventilatory periods are separated by short breathing episodes containing several ventilatory cycles. Such a pattern may be an advantage in semi-aquatic and aquatic turtles by reducing the time spend at the water surface to breathe, thereby reducing exposure time to potential predators. The length of inspiration and expiration were similar to the ones observed in other testudines (Benchetrit and Dejours, 1980; Milsom and Jones, 1980), however, the $T_{\mathrm{INSP}}, T_{\mathrm{EXP}}$, and $T_{\mathrm{TOT}}$ values 

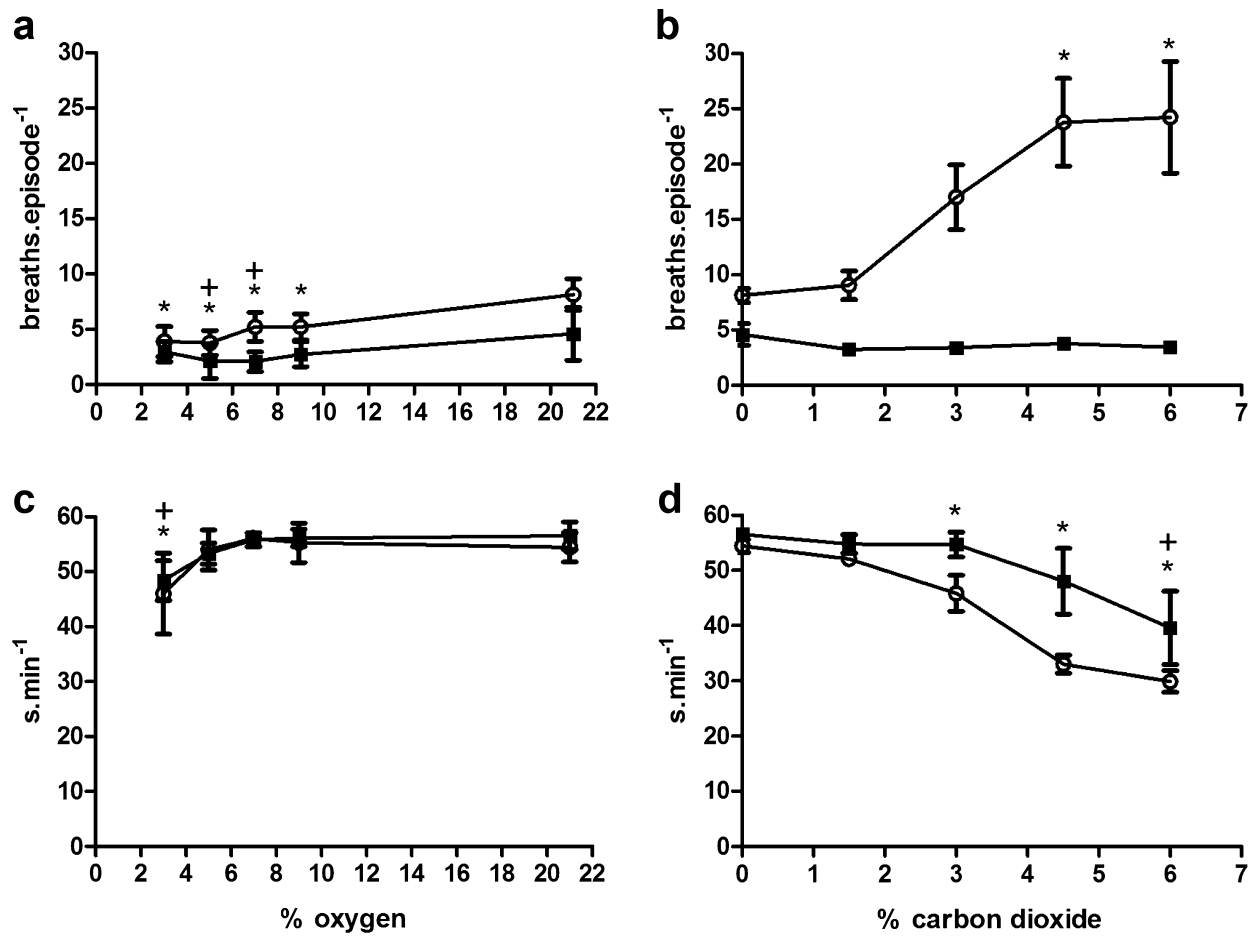

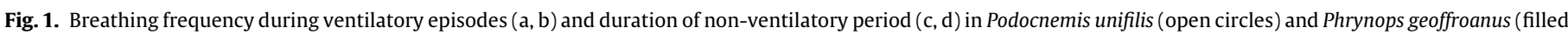
square) during hypoxic and hypercarbic exposures. * for $P$. unifilis and + for $P$. geoffroanus denote values that are significantly different from normoxic values.

of $P$. unifilis seem to be lower than previously described for other testudines.

Values for $f_{\mathrm{R}}, V_{\mathrm{T}}, \dot{V}_{\mathrm{E}}$ and $\dot{V}_{\mathrm{O}_{2}}$ of $P$. unifilis fall within the range seen in other species of chelonians (Table 1 ), with $\dot{V}_{\mathrm{O}_{2}}$ being greater than in other semi-aquatic testudines. This could indicate that animals were not fully resting during the experiments. However, due to the shortage of $\dot{V}_{\mathrm{O}_{2}}$ data from other species, no definite conclusions can be drawn.
Normoxic $f_{\mathrm{R}}$ and $V_{\mathrm{T}}$ in $P$. geoffroanus are at the lower end when compared to other species, but especially $\dot{V}_{\mathrm{E}}$ and $\dot{V}_{\mathrm{O}_{2}}$ are much lower than previously described for testudines (Table 1 ). These low values could indicate a significant extra-pulmonary gas exchange or metabolic depression during the experiments. It is well known that chelonians possess the ability to exchange gases with surrounding water (Belkin, 1968; Gage and Gage, 1886; Lengler and Winokur, 1983). Aquatic gas exchange may occur through the skin,

Table 1

Respiratory variables of Testudines during normoxia at $20-25^{\circ} \mathrm{C}$. Data are given as mean \pm standard deviation.

\begin{tabular}{|c|c|c|c|c|c|}
\hline Species & $\begin{array}{l}f_{\mathrm{R}} \\
\left(\text { breaths } \mathrm{min}^{-1} \text { ) }\right.\end{array}$ & $\begin{array}{l}\mathrm{V}_{\mathrm{T}} \\
\left(\mathrm{ml} \mathrm{kg}^{-1}\right)\end{array}$ & $\begin{array}{l}\dot{V}_{\mathrm{E}} \\
\left(\mathrm{ml} \mathrm{kg}^{-1} \mathrm{~min}^{-1}\right)\end{array}$ & $\begin{array}{l}\dot{V}_{\mathrm{O}_{2}} \\
\left(\mathrm{mlO}_{2} \mathrm{~kg}^{-1} \mathrm{~min}^{-1}\right)\end{array}$ & Source \\
\hline Apalone ferox & & & & $0.87 \pm 0.6$ & Bagatto and Henry (1999) \\
\hline Apalone spinifera & & & & $0.36 \pm 0.03$ & Bagatto and Henry (1999) \\
\hline Chelonia mydas & $0.55 \pm 0.14$ & $4.5 \pm 0.5$ & $17.5 \pm 3.2$ & $1.0 \pm 0.12$ & Jackson (1985) \\
\hline Chrysemys picta bellii & & & & $0.50 \pm 0.31$ & Stockard and Gatten (1983) \\
\hline Chrysemys picta bellii & & & $8.7 \pm 3.6$ & $0.25 \pm 0.04$ & Jackson et al. (1991) \\
\hline Chrysemys picta bellii & $1.90 \pm 0.27$ & $10.7 \pm 1.2$ & 17.5 & 0.60 & Glass et al. (1985) \\
\hline Chrysemys picta bellii & $1.9 \pm 0.3$ & $9.4 \pm 3.1$ & $16.7 \pm 4.0$ & $0.58 \pm 0.10$ & Silver and Jackson (1985) \\
\hline Chrysemys picta bellii & $1.8 \pm 0.2$ & $13.5 \pm 0.9$ & $24.8 \pm 3.4$ & & Milsom and Jones (1980) \\
\hline Pelomedusa subscrofa & $1.6 \pm 0.7$ & $33.0 \pm 26.0$ & $39.8 \pm 18.6$ & & Burggren et al. (1977) \\
\hline Pelomedusa subscrofa & $1.4 \pm 0.2$ & $15.5 \pm 2.4$ & $22.4 \pm 5.6$ & & Glass et al. (1978a,b) \\
\hline Phrynops geoffroanus & $0.6 \pm 0.27$ & $3.1 \pm 1.1$ & $1.7 \pm 0.6$ & $0.07 \pm 0.03$ & This study \\
\hline Podocnemis unifilis & $2.4 \pm 1.0$ & $9.9 \pm 1.4$ & $26.0 \pm 7.6$ & $1.13 \pm 0.7$ & This study \\
\hline Pseudemys floridana & & & 28.5 & 0.9 & Kinney and White (1977) \\
\hline Testudo graeca & & & & $1.54 \pm 0.15$ & Crawford et al. (1976) \\
\hline Testudo horsfieldi & 1.4 & 8.1 & 11.5 & & Benchetrit and Dejours (1980) \\
\hline Testudo pardalis & $2.9 \pm 2.4$ & $11.0 \pm 6.0$ & $25.7 \pm 12.5$ & & Burggren et al. (1977) \\
\hline Testudo pardalis & $2.9 \pm 0.3$ & $10.7 \pm 2.7$ & $13.4 \pm 3.6$ & & Glass et al. (1978a,b) \\
\hline Trachemys scripta & & & & $1.05 \pm 0.13$ & Bagatto and Henry (1999) \\
\hline Trachemys scripta & & & & $0.90 \pm 0.07$ & Crawford et al. (1976) \\
\hline Trachemys scripta & & & $36 \pm 4$ & & Hitzig (1982) \\
\hline Trachemys scripta & $0.82 \pm 0.2$ & $38.0 \pm 8.0$ & $31.0 \pm 4.0$ & & Hitzig and Nattie (1982) \\
\hline Trachemys scripta & $0.95 \pm 0.1$ & $20.0 \pm 3.0$ & $19.0 \pm 4.0$ & & Hitzig and Nattie (1982) \\
\hline Trachemys scripta & $1.03 .0 \pm 0.2$ & $23.0 \pm 5.0$ & $24.0 \pm 6.0$ & & Hitzig and Nattie (1982) \\
\hline Trachemys scripta & $2.0 \pm 0.07$ & $6.9 \pm 1.2$ & 13.8 & & Vitalis and Milsom (1986a,b) \\
\hline Trachemys scripta & $1.6 \pm 0.8$ & $18.5 \pm 7.0$ & $25.6 \pm 12.9$ & $0.65 \pm 0.28$ & Jackson (1971) \\
\hline Trachemys scripta & $1.40 \pm 0.15$ & & & $0.69 \pm 0.08$ & Jackson (1973) \\
\hline Trachemys scripta & $1.6 \pm 0.2$ & $15.7 \pm 2.1$ & $23.8 \pm 3.4$ & $0.70 \pm 0.08$ & Jackson et al. (1974) \\
\hline
\end{tabular}



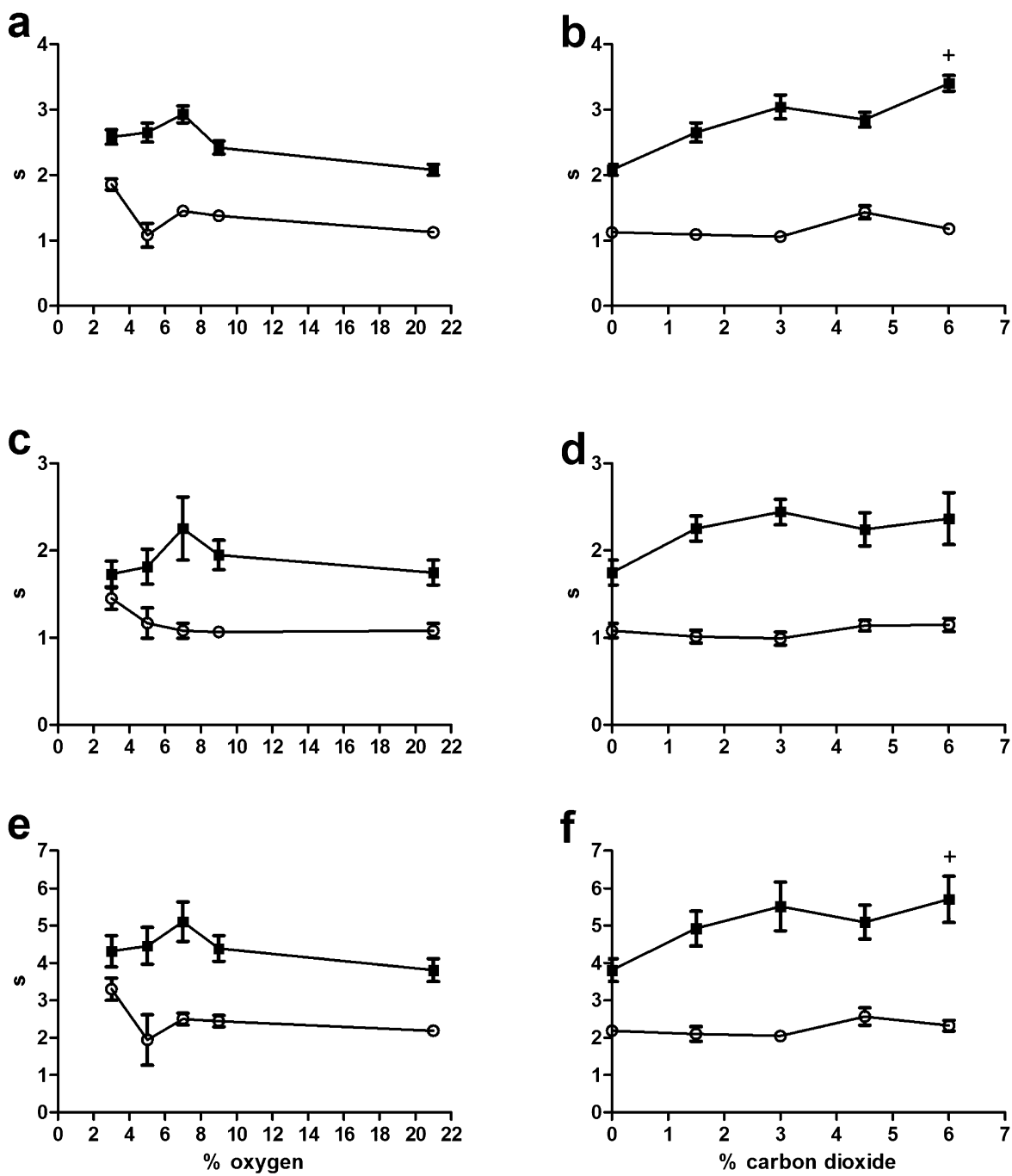

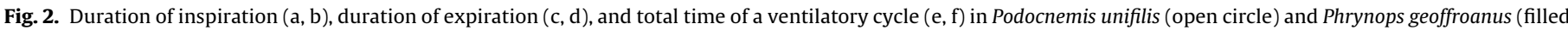
square) during hypoxic and hypercarbic exposures. * for $P$. unifilis and + for $P$. geoffroanus denote values that are significantly different from normoxic values.

buccopharyngeal epithelia, and/or the cloacal bursae (Jackson et al., 2004; King and Heatwole, 1994). Cloacal bursae are appendices to the cloaca that may be highly vascularised and used for aquatic respiration by actively ventilation the cloacal bursae with water (King and Heatwole, 1994). Future studies will be necessary to verify the existence of aquatic gas exchange in $P$. geoffroanus in order to explain the low oxygen consumption observed here.

Both species are occupying similar habitats, frequenting slow flowing rivers, lakes, lagoons or swamps (Ernst and Barbour, 1989). They have been studied regarding reproductive behavior and diet, mostly using captive animals (Malvasio et al., 2003; Souza, 2004), but aspects regarding respiratory behavior are unknown. P. unifilis, mostly herbivorous, is known to employ neustophagia, a feeding mechanism to extract food particles from the water surface (Ernst and Barbour, 1989). P. geoffroanus, a mostly carnivorous species, has been shown to dwell successfully in urban rivers (Souza and Abe, 2001) even in much polluted waters (Pinã et al., 2009). If these ecological differences are related to differences in respiratory physiology remains to be elucidated.

\subsection{Effects of hypoxia and hypercarbia}

The ventilatory responses to hypoxic and hypercarbic exposures in both species are similar and comparable to previously described results. Hypoxia results in slightly increased ventilation at severe levels of hypoxia (about $3 \% \mathrm{O}_{2}$ ) only, with tidal volume being increased more than breathing frequency to increase ventilation. Similar results regarding hypoxia have been observed as well in other chelonians (Burggren et al., 1977; Glass et al., 1983; Hitzig and Nattie, 1982; Jackson, 1973). In P. unifilis hypercarbia acted as a stronger ventilatory stimulus than hypoxia, increasing ventilation significantly at $\mathrm{CO}_{2}$ levels of 4.5 and $6 \%$, mainly due to increases in $f_{\mathrm{R}}$ and less in $V_{\mathrm{T}}$. Such responses have been found in other semi-aquatic turtles (Hitzig and Nattie, 1982; Jackson et al., 1974; Milsom and Jones, 1980; Silver and Jackson, 1985; Vitalis and Milsom, 1986b).

Oxygen consumption in $P$. unifilis followed the same pattern as ventilatory parameters, with hypercarbia significantly increasing $\dot{V}_{\mathrm{O}_{2}}$ but not hypoxia. The already very low values of $\dot{V}_{\mathrm{O}_{2}}$ found in $P$. geoffroanus were unaltered by hypercarbic exposure and increased significantly but only slightly at 3 and $5 \% \mathrm{O}_{2}$. Whether this is due to extra-pulmonary gas exchange or metabolic depression remains unknown. Air convection requirement increased significantly in both species during hypoxia and hypercarbia, just as in other chelonians (Jackson, 1973; Jackson et al., 1974).

The increases in ventilation during hypoxia or hypercarbia are achieved in both species by reducing $T_{\mathrm{NVP}}$, but maintaining $T_{\mathrm{INSP}}$ and $T_{\text {EXP }}$ constant. This pattern has been previously described 
a

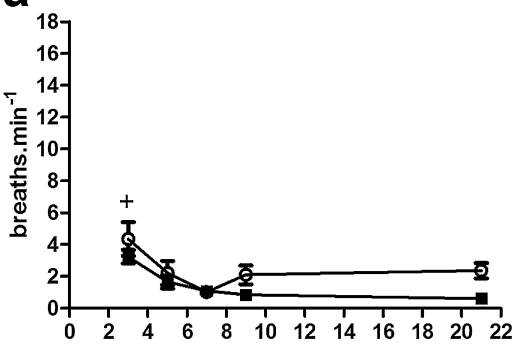

C

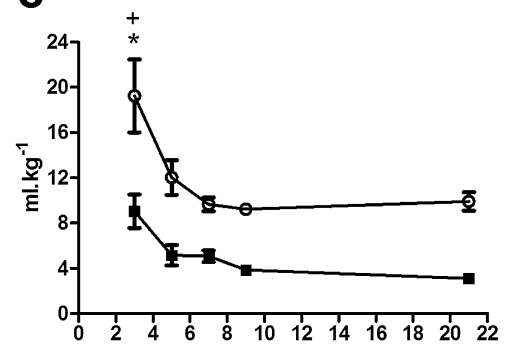

e

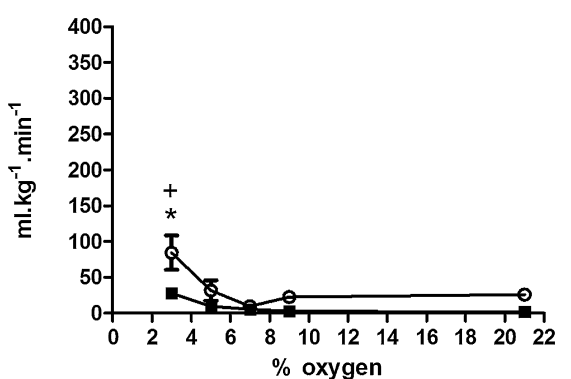

b

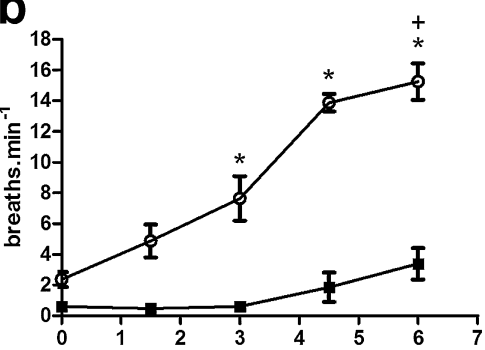

d
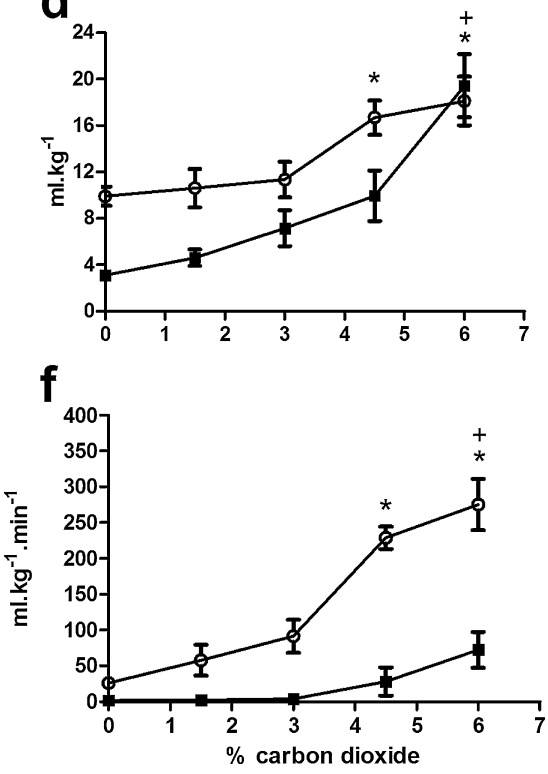

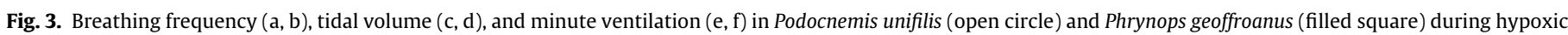
and hypercarbic exposures. ${ }^{*}$ for $P$. unifilis and + for $P$. geoffroanus denote values that are significantly different from normoxic values.

a

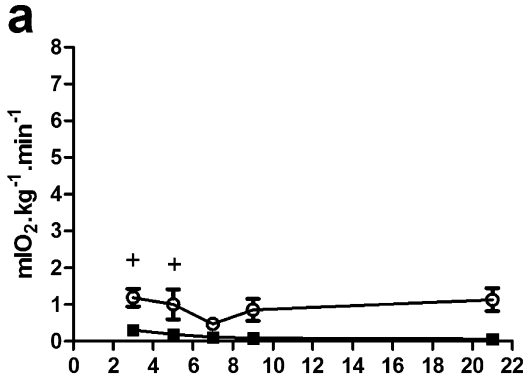

\section{C}

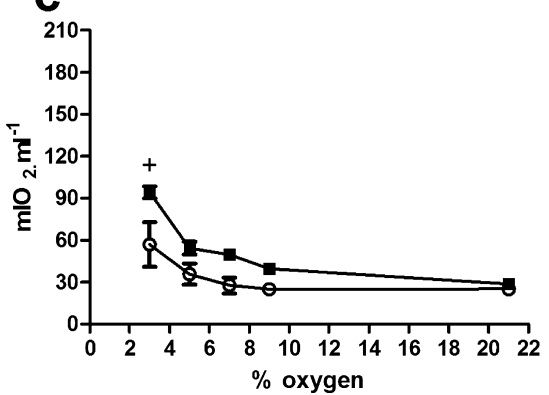

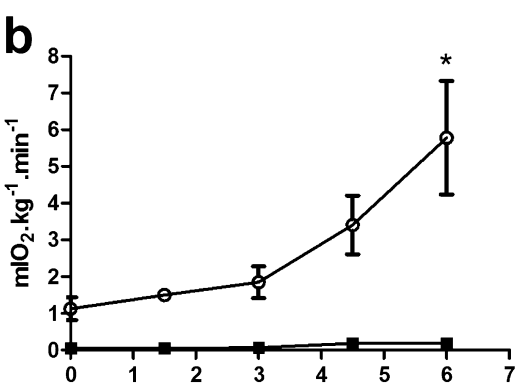

d

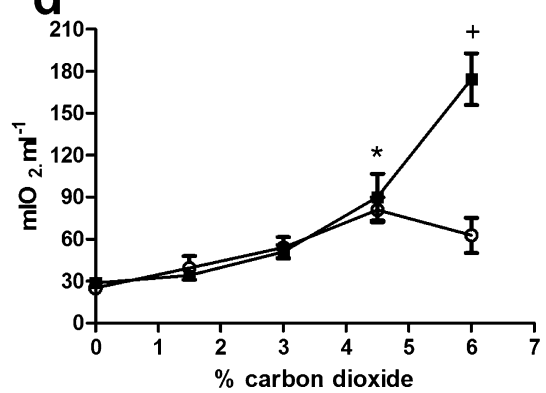

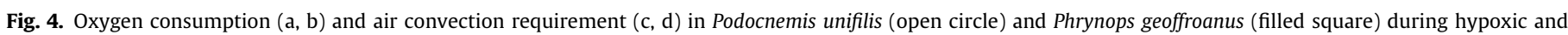
hypercarbic exposures. * for $P$. unifilis and + for $P$. geoffroanus denote values that are significantly different from normoxic values. 

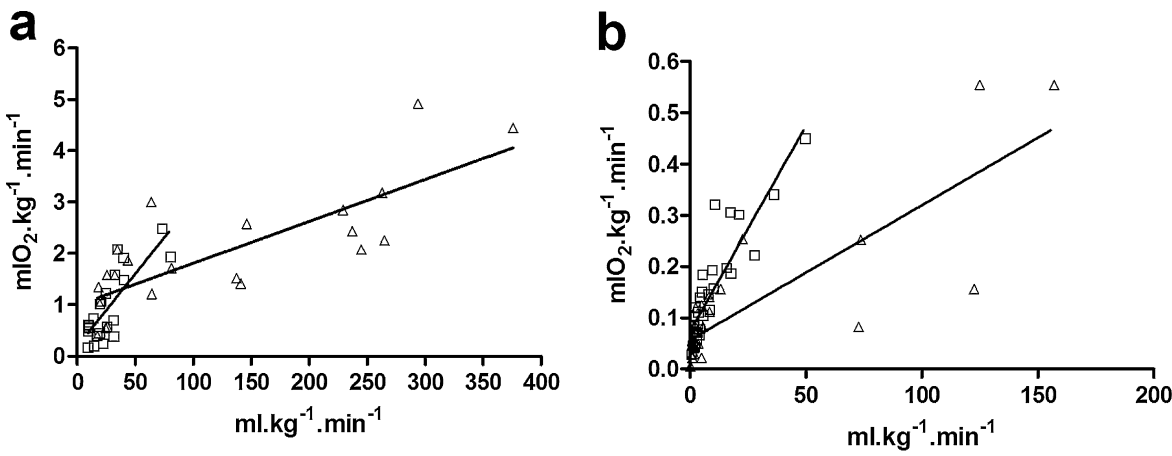

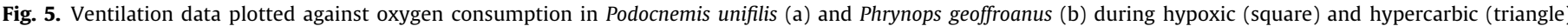

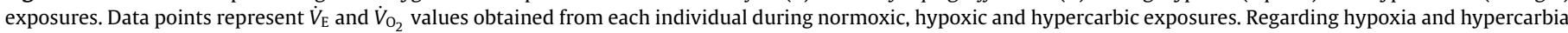
in $P$. unifilis two and three outliers, respectively, have been removed to calculate the linear regression lines given for hypoxia and hypercarbia separately.

(Milsom, 1988) and corroborates the conclusion by Vitalis and Milsom (1986b), that increases in $\dot{V}_{\mathrm{E}}$ are most economically achieved by maintaining $T_{\mathrm{INSP}}$ and $T_{\mathrm{EXP}}$ constant while reducing $T_{\mathrm{NVP}}$. The instantaneous breathing frequency $\left(f^{\prime}=60 \cdot T_{\mathrm{TOT}}^{-1}\right)$, a measure for the minimisation of mechanical work of breathing, was found to be $26.0 \pm 3.7 \mathrm{~min}^{-1}$ for $P$. unifilis and $13.3 \pm 1.7 \mathrm{~min}^{-1}$ for $P$. geoffroanus (mean and standard deviation calculated from all treatments). Vitalis and Milsom (1986b) reported $f^{\prime}$ to be $35 \pm 2 \mathrm{~min}^{-1}$ for Trachemys scripta. Whether the lower $f$ values found in the present study represent different mechanical properties of each species' respiratory system, remains to be elucidated.

\subsection{Cost of breathing}

To estimate cost of breathing, all $\dot{V}_{\mathrm{E}}$ and $\dot{V}_{\mathrm{O}_{2}}$ values from each individual during normoxia, hypoxia and hypercarbia were plotted (Fig. 5). Some values from $P$. unifilis during hypercarbic (3 data points removed) and hypoxic exposures (2 data points removed) were considered as outliers, and excluded from cost calculations. Linear regressions were calculated for hypercarbic and hypoxic exposures separately and regressions showed a good fit with $r^{2}>0.6$ in all cases. Values obtained from these regressions, however, are amongst the largest ones reported so far for reptiles (Tables 2 and 3), especially the estimate derived from hypoxic exposure in P. unifilis which is about 4.5 times larger than the largest reported so far for a resting reptile.

Estimates of oxidative cost of breathing using mainly the regression method have been attempted only in a few species of reptiles and range from $0.006 \mathrm{mlO}_{2} \mathrm{ml}^{-1}$ down to $-0.0019 \mathrm{mlO}_{2} \mathrm{ml}^{-1}$ (Table 3). Interestingly, the extremes of oxidative cost of breathing have been found in the same species, $T$. merianae, yielding estimates of relative cost of breathing of $17 \%$ and $-5 \%$, respectively (Skovgaard and Wang, 2004). In the same species, Andrade and Abe (1999) estimated cost of breathing in dormant tegu lizards
Table 2

Oxidative cost of ventilation of Podocnemis unifilis and Phrynops geoffroanus calculated using the regression method pooling individual values for a species and respiratory stimulus.

\begin{tabular}{llll}
\hline Species & Stimulus & $\begin{array}{l}\text { Oxidative cost } \\
\left(\mathrm{mlO}_{2} \mathrm{ml}^{-1}\right)\end{array}$ & $r^{2}$ \\
\hline P. unifilis & Hypoxia & 0.02826 & 0.6340 \\
P. unifilis & Hypercarbia & 0.008163 & 0.6316 \\
P. geoffroanus & Hypoxia & 0.008018 & 0.7791 \\
P. geoffroanus & Hypercarbia & 0.002628 & 0.6979 \\
\hline
\end{tabular}

to be around $52 \%$ of total metabolic rate. Such large differences in percentages of cost of breathing may be due to methodological limitations of the regression method. This method relies on the assumptions that (1) during hypoxia or hypercarbia only metabolic activity related to lung ventilation changes without metabolic changes in tissues not related to ventilation, and that (2) ventilation and oxygen consumption follow a linear relationship (Skovgaard and Wang, 2004). Since hypoxia or hypercarbia may depress metabolism, the first assumption may be violated, and estimates of oxidative cost of breathing may thus be too high. Currently, we do not know if hypoxia or hypercarbia have any depressive effect on tissue metabolism in the species studied here.

The second assumption may not have been violated in $P$. unifilis where the increase in $\dot{V}_{\mathrm{E}}$ is mainly achieved by increasing $f_{\text {Repi }}$ with several ventilatory cycles following one another without any $T_{\mathrm{NVP}}$ Since $T_{\text {INSP }}$ and $T_{\text {EXP }}$ did not change in this species, every ventilatory bout may be considered mechanically isolated from the previous one (Skovgaard and Wang, 2004). However, estimates of oxidative cost of breathing remain to be treated cautiously and different methodological approaches need to be tested. For example, using normoxic, hypoxic and hyperbaric data together suggests that a non-linear curve fit results in a better description for oxidative cost of breathing when compared to the linear regression method.

Table 3

Oxidative cost of ventilation of reptiles calculated using the regression method.

\begin{tabular}{|c|c|c|c|}
\hline Species & Stimulus & $\begin{array}{l}\text { Oxidative cost } \\
\left(\mathrm{mlO}_{2} \mathrm{ml}^{-1}\right)\end{array}$ & Source \\
\hline Alligator mississippiensis & Hypoxia & -0.0008 & Wang and Warburton (1995) \\
\hline Alligator mississippiensis & Hypercarbia & 0.005 & Wang and Warburton (1995) \\
\hline Amphisbaena alba & Hypoxia & 0.006 & Abe and Johansen (1987) \\
\hline Amphisbaena alba & Hypercarbia & 0.004 & Abe and Johansen (1987) \\
\hline Chrysemys picta & Hypercarbia & 0.00012 & Jackson et al. (1991) \\
\hline Natrix rhombifera & Hypoxia & -0.001 & Gratz (1979) \\
\hline Natrix rhombifera & Hypercarbia & 0.0003 & Gratz (1979) \\
\hline Pseudemys floridana & UDV & 0.0047 & Kinney and White (1977) \\
\hline Tupinambis merianae & Hypoxia & 0.006 & Skovgaard and Wang (2004) \\
\hline Tupinambis merianae & Hypercarbia & -0.0019 & Skovgaard and Wang (2004) \\
\hline
\end{tabular}

$\mathrm{UDV}=$ unidirectional ventilation. 
In conclusion, the present study presents the first detailed data on ventilation and gas exchange in $P$. unifilis and $P$. geoffroanus during normoxia, hypoxia and hypercarbia, revealing a significantly lower ventilation and oxygen consumption in the latter species. Future studies are warranted to better understand respiratory physiology in Phrynops species.

\section{Acknowledgements}

The Fundação de Amparo à Pesquisa do Estado de São Paulo (FAPESP) provided financial support to WK (2012/18652-1) and ASA and WK (2008/57712-4), by the Conselho Nacional de Desenvolvimento Tecnológico e Científico (CNPq) to ASA and WK (573921/2008-3). TEFC received a scholarship from the Coordenação de Aperfeiçoamento de Pessoal de Nível Superior (CAPES), and we would like to thank Prof. Dr. Mogens L. Glass and his laboratory for their support during the experiments. We also acknowledge the thourough revision of our manuscript by one anonymous reviewer.

\section{References}

Abe, A.S., Johansen, K., 1987. Gas exchange and ventilatory responses to hypoxia and hypercapnia in Amphisbaena alba (Reptilia: Amphisbaenia). J. Exp. Biol. 127, $159-172$.

Andrade, D.V., Abe, A.S., 1999. Gas Exchange and ventilation during dormancy in the tegu lizard Tupinambis merianae. J. Exp. Biol. 202, 3677-3685.

Bagatto, B.P., Henry, R.P., 1999. Aerial and aquatic respiration in the snapping turtle, Chelydra serpentina. J. Herpetol. 33, 490-492.

Belkin, D.A., 1968. Aquatic respiration and underwater survival of two freshwater turtle species. Respir. Physiol. 4, 1-14.

Benchetrit, B., Dejours, P., 1980. Ventilatory $\mathrm{CO}_{2}$ drive in the tortoise Testudo horsfieldi. J. Exp. Biol. 87, 229-236.

Bojanus, L.H., 1821. Anatome Testudinis Europaeae. Zawadzki, Vilnae, pp. 1819-1821.

Brainerd, E.L., 1999. New perspectives on the evolution of lung ventilation mechanisms in vertebrates. Exp. Biol. Online 4, 11-28.

Brainerd, E.L., Owerkowicz, T., 2006. Functional morphology and evolution of aspiration breathing in tetrapods. Respir. Physiol. Neurobiol. 54, 73-88.

Burggren, W.W., Glass, M.L., Johansen, K., 1977. Pulmonary ventilation: perfusion relationships in terrestrial and aquatic chelonian reptiles. Can. J. Zool. 55, 2024-2034.

Crawford, E.C., Gatz, R.N., Magnussen, H., Perry, S.F., Piiper, J., 1976. Lung volumes, pulmonary blood flow and carbon monoxide diffusing capacity of turtles. J. Comp. Physiol. 107, 169-178.

Druzisky, K.A., Brainerd, E.L., 2001. Buccal oscillation and lung ventilation in a semiaquatic turtle, Platysternon megacephalum. Zoology 104, 143-152.

Ernst, C.H., Barbour, R.W., 1989. Turtles of the World. Smithonian Institution Press.

Gage, R.E., Gage, S.P., 1886. Aquatic respiration in soft-shelled turtles: a contribution to the physiology of respiration in vertebrates. Am. Nat. 20,133-236.

Gans, C., Hughes, G.M., 1967. The mechanism of lung ventilation in the tortoise Testudo graeca Linne. J. Exp. Biol. 47, 1-20.

Gaunt, A.S., Gans, C., 1969. Mechanics of respiration in the snapping turtle, Chelydra serpentina. J. Morph. 128, 195-227.

Glass, M.L., Boutilier, R.G., Heisler, N., 1983. Ventilatory control of arterial $\mathrm{PO}_{2}$ in the turtle Chrysemys picta belli: effects of temperature and hypoxia. J. Comp. Physiol. $151,145-153$.

Glass, M.L., Boutilier, R.G., Heisler, N., 1985. Effect of body temperature on respiration, blood gases and acid-base status in the turtle, Chrysemys picta bellii. J. Exp. Biol. 114, 37-51.

Glass, M.L., Burggren, W.W., Johansen, K., 1978a. Ventilation in an aquatic and a terrestrial chelonian reptile. J. Exp. Biol. 72, 165-179.

Glass, M.L., Wood, S.C., Johansen, K., 1978b. The application of pneumotachography on small unrestrained animals. Comp. Biochem. Physiol. Part A 59, 425-427.

Gratz, R.K., 1979. Ventilatory response of the diamondback water snake, Natrix rhombifera, to hypoxia, hypercapnia and increase oxygen demand. J. Comp. Physiol. B 129, 105-110.

Hansemann, D.v., 1915. Die Lungenatmung der Schildkröten. Sitzungsberichte der königlich Preussischen Akademie der Wissenschaften zu Berlin, pp. 661-672.

Hitzig, B.M., 1982. Temperature induced changes in turtle CSF pH and central control of ventilation. Respir. Physiol. 49, 205-222.

Hitzig, B.M., Nattie, E.E., 1982. Acid-base stress and central chemical control of ventilation in turtles. J. Appl. Physiol. 53, 1365-1370.

Jackson, D.C., 1971. The effect of temperature on ventilation in the turtle, Pseudemys scripta elegans. Resp. Physiol. 12, 131-140.
Jackson, D.C., 1985. Respiration and respiratory control in the green turtle, Chelonia mydas. Copeia 1985, 664-671.

Jackson, D.C., 1973. Ventilatory response to hypoxia in turtles at various temperatures. Respir. Physiol. 18, 178-187.

Jackson, D.C., Palmer, S.E., Meadow, W.L., 1974. The effects of temperature and carbon dioxide breathing on ventilation and acid-base status of turtles. Respir. Physiol. 20, 131-146.

Jackson, D.C., Rauer, E.M., Feldman, R.A., Reese, S.A., 2004. Avenues of extrapulmonary oxygen uptake in western painted turtles (Chrysemys picta belli) at $10^{\circ} \mathrm{C}$. Comp. Biochem. Physiol. A 139, 221-227.

Jackson, D.C., Singer, J.H., Downey, P.T., 1991. Oxidative cost of breathing in the turtle Chrysemys picta bellii. Am. J. Physiol. Regul. Integr. Comp. Physiol. 261, R1325-R1328.

King, P., Heatwole, H., 1994. Non-pulmonary respiratory surfaces of the chelid turtle Elseya latisternum. Herpetologica 50, 262-265.

Kinney, J.L., White, F.N., 1977. Oxidative cost of ventilation in a turtle. Pseudemys floridana. Resp. Physiol. 31, 327-332.

Klein, W., Owerkowicz, T., 2006. Function of intracoelomic septa in lung ventilation of amniotes: lessons from lizards. Physiol. Biochem. Zool. 79, 1019-1032.

Lambertz, M., Böhme, W., Perry, S.F., 2010. The anatomy of the respiratory system in Platysternon megacephalum Gray, 1831 (Testudines: Cryptodira) and related species, and its phylogenetic implications. Comp. Biochem. Physiol. A 156, 330-336.

Landberg, T., Mailhot, J.D., Brainerd, E.L., 2009. Lung ventilation during treadmill locomotion in a semi-aquatic turtle, Trachemys scripta. J. Exp. Zool. 311A, 551-562.

Landberg, T., Mailhot, J.D., Brainerd, E.L., 2003. Lung ventilation during treadmill locomotion in a terrestrial turtle, Terrapene carolina. J. Exp. Biol. 206, 3391-3404

Lengler, J.M., Winokur, R.M., 1983. Vascular papillae in the buccopharyngeal mucosa of Caretochelys insculpta (Cryptodira: Carettochelydidae). Abstract, 26th Annual Meeting of The Society for Study of Amphibians and Reptiles.

Malvasio, A., Souza, A.M., Molina, F.B., Sampaio, F.A., 2003. Feeding behavior and food preference of Podocnemis expansa (Schweigger), P. unifilis (Troschel) and $P$. sextuberculata (Cornalia) in captivity (Testudines, Pelomedusidae). Rev. Brasil. Zool. 20, 161-168, turtles (Testudines, Chelidae).

McCutcheon, F.H., 1943. The respiratory mechanism in turtles. Physiol. Zool. 16, 255-269.

Milsom, W.K., Jones, D.R., 1980. The role of vagal afferent information and hypercapnia in control of the breathing pattern in chelonia. J. Exp. Biol. 87, 53-63.

Milsom, W.K., 1988. Control of arrhythmic breathing in aerial breathers. Can. J. Zool. 66, 99-108.

Milsom, W.K., Johansen, K., 1975. The effect of buoyancy induced lung volume changes on respiratory frequency in a Chelonian (Caretta caretta). J. Comp. Physiol. 98, 157-160.

Mitchell, S.W., Morehouse, G.R., 1863. Anatomy and physiology of respiration in the Chelonia. Smith. Contrib. Knowl. No. 159.

Pinã, C.I., Lance, V.A., Ferronato, B.O., Guardia, I., Marques, T.S., Verdade, L.M., 2009. Heavy metal contamination in Phrynops geoffroanus (Schweigger, 1812) (Testudines: Chelidae) in a River Basin, São Paulo, Brazil. Bull. Environ. Contam. Toxicol. 83, 771-775.

Shah, R.V., 1962. A comparative study of the respiratory muscles in chelonia. Breviora $161,1-16$.

Shaw, R.J., Baldwin, F.M., 1935. The mechanics of respiration in turtles. Copeia 1935, $12-15$.

Silva, G.S.F., Giusti, H., Branco, L.G.S., Glass, M.L., 2011. Combined ventilatory responses to aerial hypoxic and temperature in the South American lungfish Lepidosiren paradoxa. J. Thermal Biol. 36, 521-526.

Silver, R.B., Jackson, D.C., 1985. Ventilatory and acid-base response to long-term hypercapnia in the freshwater turtle, Chrysemys picta bellii. J. Exp. Biol. 144 661-672.

Skovgaard, N., Wang, T., 2004. Cost of ventilation and effect of digestive state on the ventilatory response of the tegu lizard. Resp. Physiol. Neurobiol. 141, 85-97.

Souza, F.L., 2004. A review on activity patterns, reproduction, and feeding habits in Brazilian chelid. turtles (Testudines, Chelidae). Phyllomedusa 3, 15-27.

Souza, F.L., Abe, A.S., 2001. Population structure and reproductive aspects of the freshwater turtle, Phrynops geoffroanus, inhabiting an urban river in Southeastern Brasil. Studies Neotrop. Fauna Environ. 36, 57-62.

Sterli, J., Pol, D., Laurin, M., 2013. Incorporating phylogenetic uncertainty on phylogeny-based palaeontological dating and the timing of turtle diversification. Cladistics 29, 233-246.

Stockard, M.E., Gatten Jr., R.E., 1983. Activity metabolism of painted turtles (Chrysemys picta). Copeia 1983, 214-221.

Townson, R., 1799. Tracts and Observations in Natural History and Physiology. J. White, Fleet-Street, London, pp. 1799.

Vitalis, T.Z., Milsom, W.K., 1986a. Pulmonary mechanics and the work of breathing in the semi aquatic turtle, Pseudemys scripta. J. Exp. Biol. 125, 137-155.

Vitalis, T.Z., Milsom, W.K., 1986b. Mechanical analysis of spontaneous breathing in the semi-aquatic turtle, Pseudemys scripta. J. Exp. Biol. 125, 157-171.

Wang, T., Warburton, S.J., 1995. Breathing pattern and cost of ventilation in the American alligator. Respir. Physiol. 102, 29-37. 